\title{
A Tree-Centered Approach to Assess Impacts of Extreme Climatic Events on Forests
}

\begin{abstract}
Ute Sass-Klaassen ${ }^{1 *}$, Patrick Fonti ${ }^{2}$, Paolo Cherubini ${ }^{2}$, Jožica Gričar ${ }^{3}$, Elisabeth M. R. Robert ${ }^{4,5,6}$, Kathy Steppe ${ }^{7}$ and Achim Bräuning ${ }^{8}$
\end{abstract}

${ }^{1}$ Forest Ecology and Forest Management Group, Wageningen University, Wageningen, Netherlands, ${ }^{2}$ Landscape Dynamics Unit, Swiss Federal Institute for Forest, Snow and Landscape Research WSL, Birmensdorf, Switzerland, ${ }^{3}$ Department of Forest Yield and Silviculture, Slovenian Forestry Institute, Ljubljana, Slovenia, ${ }^{4}$ CREAF, Cerdanyola del Vallès, Spain, ${ }^{5}$ Laboratory of Plant Biology and Nature Management, Vrije Universiteit Brussel, Brussels, Belgium, ${ }^{6}$ Laboratory of Wood Biology and Xylarium, Royal Museum for Central Africa, Tervuren, Belgium, ${ }^{7}$ Laboratory of Plant Ecology, Department of Applied Ecology and Environmental Biology, Faculty of Bioscience Engineering, Ghent University, Ghent, Belgium, ${ }^{8}$ Department of Geography and Geosciences, Friedrich-Alexander-University Erlangen-Nuremberg, Erlangen, Germany

Keywords: climate change, future forests, tree, mechanistic understanding, structure-function relationships, long-term monitoring, intra-annual resolution, resilience

\section{INTRODUCTION}

A major task of our society is to manage forests in a way that their resources are preserved to meet future generation needs (Forest Europe et al., 2015). Current scenarios of climate change effects are

OPEN ACCESS

Edited by:

Judy Simon,

University of Konstanz, Germany

Reviewed by:

Martin De Luis,

University of Zaragoza, Spain

*Correspondence:

Ute Sass-Klaassen

ute.sassklaassen@wur.nl

Specialty section:

This article was submitted to

Functional Plant Ecology,

a section of the journal

Frontiers in Plant Science

Received: 25 May 2016

Accepted: 06 July 2016

Published: 21 July 2016

Citation:

Sass-Klaassen U, Fonti P, Cherubini P, Gričar J, Robert EMR, Steppe K and Bräuning A (2016) A Tree-Centered Approach to Assess Impacts of Extreme Climatic Events on Forests.

Front. Plant Sci. 7:1069.

doi: 10.3389/fpls.2016.01069 making this task extremely challenging (Kirilenko and Sedjo, 2007). Climate shifts will impact forest vitality and affect goods and services forests provide, including carbon sequestration and climate change mitigation (IPCC, 2014). To guide sustainable forest management, forest researchers are asked to provide concrete answers about forest resilience in response to expected climatic trends, and extreme climatic events (Lindner et al., 2014). This is not an easy task, because responses of trees and forest ecosystems to environmental conditions are often non-linear and moreover vary on spatial and temporal scales (Smith, 2011; Anderegg et al., 2012; Reichstein et al., 2013). For instance, although drought is one of the most frequent and widespread climatic extremes affecting forests worldwide (e.g., Allen et al., 2010), the assessment of its impact on future forests is currently under intense debate. Mechanisms behind tree growth and mortality are complex (McDowell et al., 2008, 2011; Fatichi et al., 2014; Anderegg et al., 2015; Meir et al., 2015). Besides strength or frequency of external factors, such as extreme events, also the tree's ability to resist and recover is relevant, which, in turn, is largely determined by intrinsic factors such as the tree's life stage, life history, and genetic characteristics.

In this paper, we advocate for a tree-centered approach. By providing an improved mechanistic understanding of physiological and growth responses of trees growing under various conditions we can define the tree's capacity to respond to external stress factors. This concept can valuably contribute to the debate on how to shape future forests toward resilient forest ecosystems.

\section{A TREE-CENTERED APPROACH}

Current spatiotemporal simulations on future forest growth responses to changing climate conditions are performed with dynamic global vegetation models (DGVMs; Wullschleger et al., 2014). These models - usually generalizing tree species as plant functional types (PFTs) - provide valuable descriptions of the evolution of natural vegetation at a grid cell level under several climate scenarios. Such approaches are powerful in assessing growth responses related to the interaction 
between vegetation and atmosphere (including anthropogenic impact). However, although first steps toward representation of tree species, size classes, and forest structure in a DGVM were recently made (e.g., Naudts et al., 2016) they often lack to explain the variability between and within species, and often do not adequately explain growth responses (Fatichi et al., 2014) under varying site conditions, and to climatic extremes (Anderegg et al., 2015). These aspects are however extremely relevant to evaluate plasticity of tree individuals and tree species and the resilience of forests under changing climatic conditions, especially considering changing frequencies and intensities of climatic extremes (Reyer et al., 2013).

The tree-centered approach proposed here considers the individual tree as main source of information for understanding variability in growth responses. Comprehensive investigations using well-selected trees growing under different environmental conditions foster a better understanding of projected largescale forest responses to changing climate. In comparison to generalizing approaches using PFTs, the tree-centered approach yields information with less spatial coverage but with the potential to convey more details on specific tree responses to a given climatic factor. This knowledge complements other approaches and can for instance support forest managers in tree species and/or provenance selection to better prepare specific forest stands to cope with expected challenges.

\section{FOUR IMPORTANT ELEMENTS}

The incentive for the tree-centered approach is gaining a process-based understanding on tree responses to changing environmental conditions on temporal scales varying from shortterm responses to climatic extreme events to long time periods matching the life cycles of tree populations. This can be achieved through an ensemble of observational studies on a selection of trees from different species and life histories, growing in diverse settings (forest types, species composition, successional stages, management regimes), and exposed to different climates and extreme climatic events. Establishing such a model framework requires the following elements:

(i) In-depth understanding of causal processes occurring within the tree in response to environmental changes. The cascade of physiological and growth responses is assessed by an integration of real-time observations of physiological and structural growth responses.

(ii) Assessment of the link between tree structure and function. This allows for evaluation of the short-term impact of extreme events on tree functioning as a consequence of resulting structural changes in tree morphology as well as wood and bark structure.

(iii) A long-term temporal perspective to verify the link between a specific event and related responses. Here we take advantage of the fact that trees rigorously archive growth responses within their datable annual tree rings. Dendrochronology provides this necessary historical perspective for quantifying resilience by assessing impacts of past events. (iv) Comparative studies in selected sites experiencing extreme events, long-term manipulation studies, and experiments, including e.g., provenance trials are finally necessary to test and validate the model framework to conditions expanding even far outside today's natural range.

\section{IMPLEMENTATION OF THE TREE-CENTERED APPROACH}

The COST Action STReESS-a 4-year European framework initiative to promote networking among researchers of several plant-research disciplines to study tree responses to extreme events-is demonstrating the potential of such an integrated bottom-up approach. Starting from an enhanced understanding of the physiological processes behind wood formation, the STReESS Action established a modular process-based approach, which will eventually result in a model framework for explaining tree responses to climate extremes (Figure 1).

The COST Action STReESS contributed to the following main interlinked elements of the concept along the causal path: environmental trigger-structure-function-performance.

\section{Long-Term High-Resolution Monitoring}

Efforts performed for long-term high-resolution monitoring of tree physiology, tree growth together with contemporary site, and climatic factors, allows quantifying causal relationships between external triggers and tree physiological and growth responses (Steppe et al., 2015, 2016). Knowledge gained from such real-time measurements has resulted in process-based plant models in which the mechanisms underlying diel water and carbon transport and their tight coupling have been integrated (see review by De Swaef et al., 2015). In addition, worldwide xylogenesis and dendrometer databases have been compiled during the STReESS Action to assess global response patterns to various specific climate and site conditions (Rossi et al., 2013) and to gain insight into processes involved in wood formation (Cuny et al., 2014, 2015; Steppe et al., 2015).

\section{Linking Structure to Function}

Linking structure to function is vital to understand the impact of climate-caused changes on wood formation dynamics and wood structure, which strongly influences the water, and carbon household and determines actual, and future tree survival chances and growth performance. Recent studies have highlighted that tree morphological properties and related e.g., hydraulic safety properties (Delzon and Cochard, 2014) vary within individuals, among provenances and species, or along environments and stress gradients. Relevant parameters include phloem to xylem ratio (Gričar et al., 2015; Jyske et al., 2015) and connection (Pfautsch et al., 2015), as well as xylem and phloem-cell characteristics in stems (Anfodillo et al., 2012; Olano et al., 2013; Carrer et al., 2015; Gričar et al., 2016), branches (Salmon et al., 2015), and roots (Brunner et al., 2015). Such characteristics reflect functional adjustments in the tree's structures in response to changing environmental conditions. In turn, these adjustments also form a legacy by influencing future tree performance and hence reflecting the acclimation capacity 


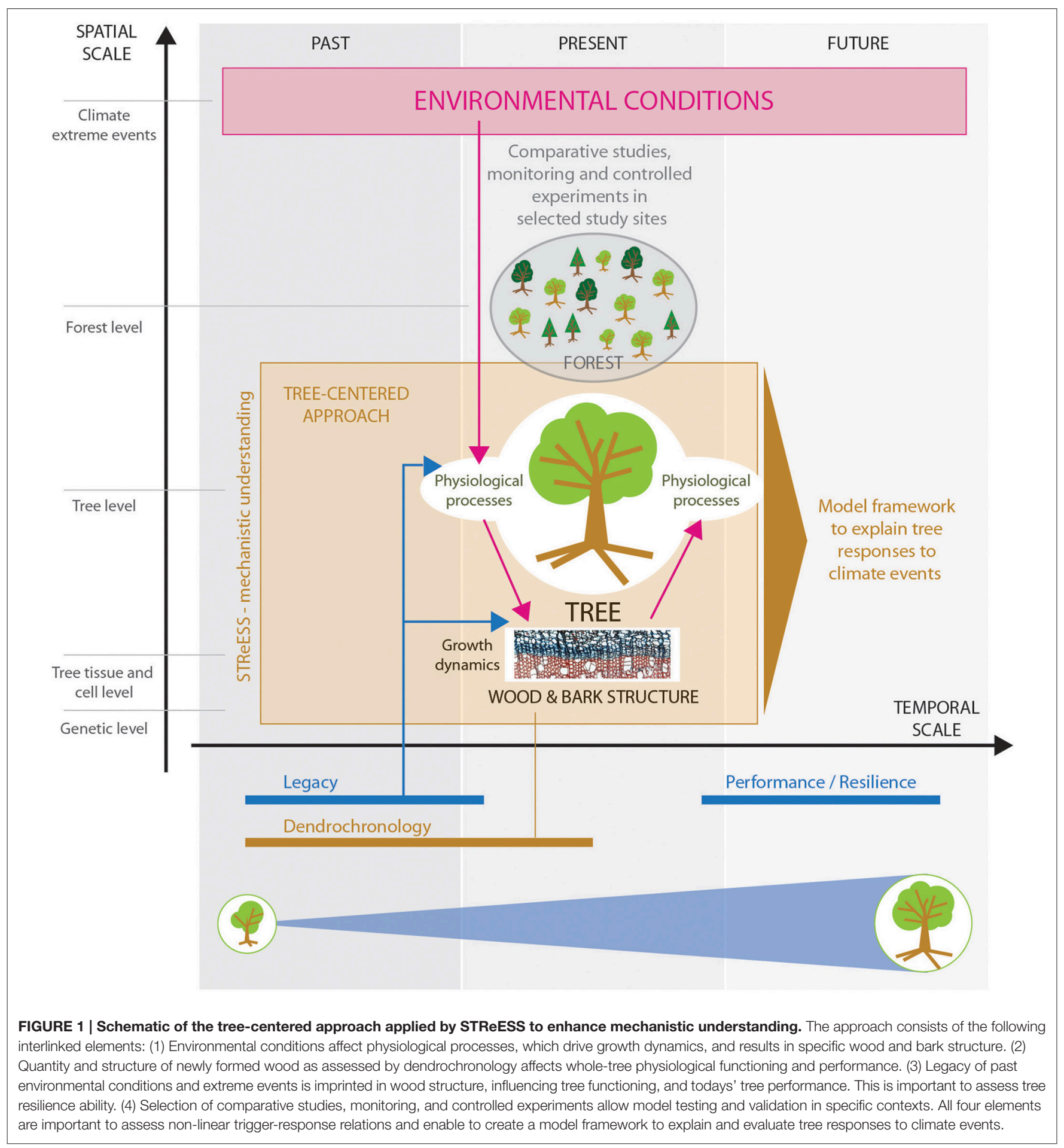

of trees and tree species (Lachenbruch and McCulloh, 2014; Rosner et al., 2016a,b; Sterck et al., 2016; Anfodillo et al., in review).

\section{The Long-Term Perspective}

The continuous adjustments in wood structure are permanently stored in tree rings either as annual variations in wood-anatomical characteristics, such as cell-wall thickness, cell size, or tissue percentage, or in case of extreme climatic events, as obvious wood-anatomical markers (Battipaglia et al., 2016; Bräuning et al., 2016). These characteristics enable the use of dated tree rings to reconstruct how trees have been growing and functioning in the past (Fonti and Jansen, 2012), and consequently reflect the resilience and acclimation strategies 
of trees in a changing climate (e.g., Breda et al., 2006). Typical cases of wood-anatomical markers considered in the STReESS action are flood rings (Copini et al., 2016), missing rings and dark rings (Novak et al., 2016), and intra-annual density fluctuations (IADFs). IADFs comprise an abrupt change in wood density in a given tree ring (Nabais et al., 2014; Campelo et al., 2015) and have been demonstrated to hold valuable high-resolution information on the timing of past droughts in Mediterranean conifers (Battipaglia et al., 2016; De Micco et al., 2016; Zalloni et al., 2016). Recently, these approaches became increasingly applicable due to methodological advances in efficiently quantifying cell-lumen size, cell-wall thickness or specific cell types as resin canals, and parenchyma cells (von Arx and Carrer, 2014; von Arx et al., 2016). The enormous potential of wood-anatomical characteristics and markers lies in the information they provide on the exact timing of climatic constraints (Fonti et al., 2010; Rathgeber et al., 2016) and in the possibility to evaluate consequences that these constraints have for xylem and phloem functioning. This creates the bridge between the elements 1 and 2 and allows to uniquely integrating a long-term functional perspective on the current assessment of tree-growth responses to the environment.

\section{Field Studies, Provenance Trials, Manipulation Experiments}

The limit of spatial coverage in the high-resolution monitoring approach (element 1) together with the need for testing the effect of future climate-change scenarios on tree performance can be waged by comparative field and experimental studies to target specific species, provenances, or environmental conditions. De Luis et al. (2014) illustrated the potential of using tree-ring networks across species distributions to assess local adaptation and plasticity of Pinus halepensis in the Mediterranean basin. Another approach is a transEuropean cross experiment where drought mortality-resistance of European beech provenances has been related to water availability and to the origin of the beech seedlings (Pšidová et al., 2015; Bolte et al., 2016). Hence, provenance trials have revealed a genetic control of wood structural properties (Eilmann et al., 2014; Nabais et al., in review), although investigations of other tree species are needed to fully evaluate the importance of genetic preadaptation to future climatic conditions. Such kinds of studies prove the added value of targeting specific situations, e.g., natural conditions or manipulated experiment, for developing, and validating the model framework.

\section{Integration into a Model Framework}

The four elements can be captured and integrated into process-based tree models. The first steps of this integration have already been achieved. For example, diel stem-size variations and sap-flux densities combining real-time and highresolution measurements of tree functioning under on-site environmental conditions have allowed to link environmental triggers (climate events) with the resulting tree growth and performance (e.g., Steppe et al., 2006; De Schepper and Steppe, 2010; Hölttä et al., 2010; Schiestl-Aalto et al., 2015). This means that instant responses of a tree to a drought or a heat wave (Teskey et al., 2015) can be readily assessed, and changes in its water and carbon budget quantified. Effort still needs to be invested to implement parameterizing of long-term climate-growth responses or the peculiarity of species and proveniences into the existing models to finally come up with estimates for tree plasticity, acclimation potential of tree species, and ultimately resilience of forests.

\section{CONCLUSION AND PERSPECTIVE}

There is a fundamental difference between generalized PFTbased approaches (i.e., DGVMs) and tree-centered approaches. While PFT-based approaches perform spatially explicit "scenarios" of future global responses, the interdisciplinary process-driven tree-centered approach has potential to also provide practical support for local management decisions based on a solid understanding of tree functioning under specific site conditions. The COST Action STReESS has improved our understanding on the variability of responses to climate trends and extreme events. After 4 years of collaboration, the consortium has collected indications of the usefulness of such an integrated approach with continuous "methodological" development, and creativity. Through the integration of monitoring studies (e.g., time series of dendrometers, wood formation, and forest inventories), dendrochronological approaches, manipulation experiments (e.g., induced drought stress), and process-based models (e.g., at the cell, plant, or vegetation level) there is potential to collect valuable characterization to build process-based tree models accounting for variability between species, provenances, sites, and climatic events. This will contribute to unraveling a large set of yet unanswered questions related to processes of tree mortality (e.g., McDowell et al., 2011) or (mal)-adaptation (e.g., Martinez-Meier et al., 2008). Such a process-based approach will help to reduce uncertainty on tree performance under future environmental conditions.

Actual plans include the extension of the twittering-tree network for further development of a near real-time detection of tree processes and environmental impacts (Steppe et al., 2016) as well as the extension of global data networks and harmonization of protocols for high-resolution growth measurements (e.g., dendrometer, xylogenesis).

Despite still many implementation challenges ahead, we believe that the tree-centered approach offers an additional opportunity to assess forest management sustainability at the profit of the whole society.

\section{AUTHOR CONTRIBUTIONS}

All authors developed the concept and structure of the manuscript. USK and PF wrote the first draft of the manuscript. EMRR developed and designed the figure in cooperation with PF 
and USK. AB, EMRR, KS, JG, and PC authors accomplished and checked the first version and read and approved the submitted version.

\section{ACKNOWLEDGMENTS}

We thank all COST STReESS participants for an inspiring 4-year period of fruitful collaboration. Our opinion paper as part of this

\section{REFERENCES}

Allen, C. D., Macalady, A. K., Chenchouni, H., Bachelet, D., McDowell, N.,Vennetier, M., et al. (2010). A global overview of drought and heat-induced tree mortality reveals emerging climate change risks for forests. For. Ecol. Manag. 259, 660-684. doi: 10.1016/j.foreco.2009.09.001

Anderegg, W. R., Kane, J. M., and Anderegg, L. D. (2012). Consequences of widespread tree mortality triggered by drought and temperature stress. Nat. Clim. Chang. 3, 30-36. doi: 10.1038/nclimate1635

Anderegg, W. R. L., Flint, A., Huang, C. Y., Flint, L., Berry, J. A., Davis, F. W., et al. (2015). Tree mortality predicted from drought-induced vascular damage. Nat. Geosci. 8, 367-371. doi: 10.1038/ngeo2400

Anfodillo, T., Deslauriers, A., Menardi, R., Tedoldi, L., Petit, G., and Rossi, S. (2012). Widening of xylem conduits in a conifer tree depends on the longer time of cell expansion downwards along the stem. J. Exp. Bot. 63, 837-845. doi: 10.1093/jxb/err309

Battipaglia, G., Campelo, F., Vieira, J., Grabner, M., De Micco, V., Nabais, C., et al. (2016). Structure and function of intra-annual density fluctuations: mind the gaps. Front. Plant Sci. 7:595. doi: 10.3389/fpls.2016.00595

Bolte, A., Czajkowski, T., Cocozza, C., Tognetti, R., De Miguel, M., Pšidová, E., et al. (2016). Desiccation and mortality dynamics in seedlings of different European beech (Fagus sylvatica L.) populations under extreme drought conditions. Front. Plant Sci. 7:751. doi: 10.3389/fpls.2016.00751

Bräuning, A., De Ridder, M., Zafirov, N., García-González, I., Dimitrov, D., and Gärtner, H. (2016). Tree-ring features - indicators of extreme event impacts. IAWA 37, 206-231. doi: 10.1163/22941932-20160131

Breda, N., Huc, R., Granier, A., and Dreyer, E. (2006). Temperate forest trees and stands under severe drought: a review of ecophysiological responses, adaptation processes and long-term consequences. Ann. For. Sci. 63, 625-644. doi: 10.1051/forest:2006042

Brunner, I., Herzog, C., Dawes, M. A., Arend, M., and Sperisen, C. (2015). How tree roots respond to drought. Front. Plant Sci. 6:547. doi: 10.3389/fpls.2015. 00547

Campelo, P., Vieira, J., Battipaglia, G., de Luis, M., Nabais, C., Freitas, H., et al. (2015). Which matters most for the formation of intra-annual density fluctuations in Pinus pinaster: age or size? Trees 29, 237-245. doi: 10.1007/s00468-014-1108-9

Carrer, M., von Arx, G., Castagneri, D., and Petit, G. (2015). Distilling allometric and environmental information from time series of conduit size: the standardization issue and its relation to tree hydraulic architecture. Tree Physiol. 35, 27-33. doi: 10.1093/treephys/tpu108

Copini, P., den Ouden, J., Robert, E. M. R., Tardif, J., Loesberg, W. A., Goudzwaard, L., et al. (2016). Flood-ring formation and root development in response to experimental flooding of young Quercus robur trees. Front. Plant Sci. 7:775. doi: $10.3389 /$ fpls.2016.00775

Cuny, H. E., Rathgeber, C. B. K., Frank, D., Fonti, P., and Fournier, M. (2014). Kinetics of tracheid development explain conifer tree-ring structure. New Phytol. 203, 1231-1241. doi: 10.1111/nph.12871

Cuny, H. E., Rathgeber, C. B. K., Frank, D., Fonti, P., Mäkinen, H., Prislan, P., et al. (2015). Woody biomass production lags stem-girth increase by over one month in coniferous forests. Nat. Plants 1:15160. doi: 10.1038/nplants. 2015.160

De Luis, M., Čufar, K., Di Filippo, A., Novak, K., Papadopoulos, A., Piovesan, G., et al. (2014). Plasticity in dendroclimatic response across the distribution range of Aleppo Pine. PLoS ONE 8:e83550. doi: 10.1371/journal.pone.0083550 special issue is one product of the COST Action FP1106 STReESS besides the many other common research articles, review papers, book chapters and films. Moreover the COST Action has resulted in numerous collaborations, projects and project initiatives. EMRR is funded by the Research Foundation-Flanders (FWO, Belgium) and by the EU through a Marie Curie IF fellowship (No 659191). This work profited from support from the Swiss COST project D-STReSS.ch (C12.0100).
Delzon, S., and Cochard, H. (2014). Recent advances in tree hydraulics highlight the ecological significance of the hydraulic safety margin. New Phytol. 203, 355-358. doi: 10.1111/nph.12798

De Micco, V., Balzano, A., Cufar, K., Aronne, G., Grièar, J., Merela, M., et al. (2016). Timing of false ring formation in Pinus halepensis and Arbutus unedo in Southern Italy: outlook from an analysis of xylogenesis and tree-ring chronologies. Front. Plant Sci. 7:705. doi: 10.3389/fpls.2016.00705

De Schepper, V., and Steppe, K. (2010). Development and verification of a water and sugar transport model using measured stem diameter variations. J. Exp. Bot. 61, 2083-2099. doi: 10.1093/jxb/erq018

De Swaef, T., De Schepper, V., Vandegehuchte, M. W., and Steppe, K. (2015). Stem diameter variations as a versatile research tool in ecophysiology. Tree Physiol. 35, 1047-1061. doi: 10.1093/treephys/tpv080

Eilmann, B., Sterck, F. J., Wegner, L., Vries, S. M. G., de Arx, G., von Mohren, G. M. J., et al. (2014). Wood structural differences between northern and southern beech provenances growing at a moderate site. Tree Physiol. 34, 882-893. doi: 10.1093/treephys/tpu069

Fatichi, S., Leuzinger, S., and Körner, S. (2014). Moving beyond photosynthesis: from carbon source to sink-driven vegetation modeling. New Phytol. 201, 1086-1095. doi: 10.1111/pce.12141

Fonti, P., and Jansen, S. (2012). Xylem plasticity in response to climate. New Phytol. 195, 734-736. doi: 10.1111/j.1469-8137.2012.04252

Fonti, P., von Arx, G., Garcia-Gonzalez, I., Eilmann, B., Sass-Klaassen, U., Gärtner, H., et al. (2010). Studying global change through investigation of the plastic responses of xylem anatomy in tree rings. New Phytol. 185, 42-53. doi: $10.1111 / j .1469-8137.2009 .03030$

Forest Europe, UNECE, and FAO (2015). "State of Europe's forests 2015," in Ministerial Conference on the Protection of Forests in Europe (Madrid), 314.

Gričar, J., Prislan, P., De Luis, M., Gryc, V., Hacurova, J., Vavrèík, H., et al. (2015). Plasticity in variation of xylem and phloem cell characteristics of Norway spruce under different local conditions. Front. Plant Sci. 7:730. doi: $10.3389 /$ fpls.2015.00730

Gričar, J., Prislan, P., De Luis, M., Novak, K., Longares, L. A., Martinez del Castillo, E., et al. (2016). Lack of annual periodicity in cambial production of phloem in trees from Mediterranean areas. IAWA 37, 349-364. doi: 10.1163/2294193220160138

Hölttä, T., Mäkinen, H., Nöjd, P., Mäkelä, A., and Nikinmaa, E. (2010). A physiological model of softwood cambial growth. Tree Physiol. 30, 1235-1252. doi: $10.1093 /$ treephys/tpq068

IPCC (2014). "Climate Change 2014: impacts, adaptation, and vulnerability. part a: global and sectoral aspects," in Contribution of Working Group II to the Fifth Assessment Report of the Intergovernmental Panel on Climate Change, eds. C. B. Field, V. R. Barros, D. J. Dokken, K. J. Mach, M. D. Mastrandrea, T. E. Bilir, et al. (Cambridge; New York, NY: Cambridge University Press), 1132.

Jyske, T. M., Suuronen, J.-P., Pranovich, A. V., Laakso, T., Watanabe, U., Kuroda, K., et al. (2015). Seasonal variation in formation, structure, and chemical properties of phloem in Picea abies as studied by novel microtechniques. Planta 242, 613-629. doi: 10.1007/s00425-015-2347-8

Kirilenko, A. P., and Sedjo, A. (2007). Climate change impacts on forestry. Proc. Natl. Acad. Sci. U.S.A. 104, 19697-19702. doi: 10.1073/pnas.0701424104

Lachenbruch, B., and McCulloh, K. A. (2014). Traits, properties, and performance: how woody plants combine hydraulic and mechanical functions in a cell, tissue, or whole plant. New Phytol. 204, 747-764. doi: 10.1111/nph.13035

Lindner, M., Fitzgerald, J., Zimmermann, N., Reyer, C., Delzon, S., Maaten, E., et al. (2014). Climate change and European forests: what do we know, what are the 
uncertainties, and what are the implications for forest management? Environ. Manag. 146, 69. doi: 10.1016/j.jenvman.2014.07.030

Martinez-Meier, A., Sanchez, L., Pastorino, M., Gallo, L., and Rozenberg, P. (2008). What is hot in tree rings? the wood density of surviving douglasfirs to the 2003 drought and heat wave. For. Ecol. Manag. 256, 837-843. doi: 10.1016/j.foreco.2008.05.041

McDowell, N. G., Beerling, D. J., Breshears, D. D., Fisher, R. A., Raffa, K. F., and Stitt, M. (2011). The interdependence of mechanisms underlying climate-driven vegetation mortality. Trends Ecol. Evol. 26, 523-532. doi: 10.1016/j.tree.2011.06.003

McDowell, N. G., Pockman, W. T., Allen, C. D., Breshears, D. D., Cobb, N., Kolb, T., et al. (2008). Mechanisms of plant survival and mortality during drought: why do some plants survive while others succumb to drought? New Phytol. 178, 719-739. doi: 10.1111/j.1469-8137.2008.02436

Meir, P., Mencuccini, M., and Dewar, R. C. (2015). Drought-related tree mortality: addressing the gaps in understanding and prediction. New Phytol. 207, 28-33. doi: 10.1111/nph.13382

Nabais, C., Campelo, F., Vieira, J., and Cherubini, P. (2014). Climatic signals of tree-ring width and intra-annual density fluctuations in Pinus pinaster and Pinus pinea along a latitudinal gradient in Portugal. Forestry 87, 598-605. doi: $10.1093 /$ forestry/cpu021

Naudts, K., Chen, Y., McGrath, M. J., Ryder, J., Valade, A., Otto, J., et al. (2016). Europe's forest management did not mitigate climate warming. Science 351, 597-600. doi: 10.1126/science.aad7270

Novak, K., De Luis, M., Angel Saz, M., Longares, L. A., Serrano Notivoli, R., et al. (2016). Missing rings in Pinus halepensis - the missing link to relate the tree-ring record to extreme climatic Front. Plant Sci. 7:727. doi: 10.3389/fpls.2016.00727

Olano, J. M., Almería, I., Eugenio, M., and von Arx, G. (2013). Under pressure: how a Mediterranean high-mountain forb coordinates growth and hydraulic xylem anatomy in response to temperature and water constraints. Funct. Ecol. 27, 1295-1303. doi: 10.1111/1365-2435.12144

Pfautsch, S., Hölttä, T., and Mencuccini, M. (2015). Hydraulic functioning of tree stems-fusing ray anatomy, radial transfer and capacitance. Tree Physiol. 35, 706-722. doi: 10.1093/treephys/tpv058

Pšidová, E., Ditmarová, L., Jamnická, G., Kurjak, D., Majerová, J., Czajkowski, T., et al. (2015). Photosynthetic response of beech seedlings of different origin to water deficit. Photosynthetica 53, 187-194. doi: 10.1007/s11099-015-0101

Rathgeber, C. B., Cuny, H. E., and Fonti, P. (2016). Biological basis of treering formation: a crash course. Front. Plant Sci. 7:734. doi: 10.3389/fpls.2016. 00734

Reichstein, M., Bahn, M., Ciais, P., Frank, D., Mahecha, M. D., Seneviratne, S. I., et al. (2013). Climate extremes and the carbon cycle. Nature 500, 287-295. doi: 10.1038 /nature 12350

Reyer, C. P. O., Leuzinger, S., Rammig, A., Wolf, A., Bartholomeus, R. P., Bonfante, A., et al. (2013). A plant's perspective of extremes: terrestrial plant responses to changing climatic variability. Glob. Change Biol. 19, 75-89. doi: $10.1111 /$ gcb. 12023

Rosner, S., Luss, S., Sve, J., Andreassen, K., Børja, I., Dalsgaard, L., et al. (2016b). Chronology of hydraulic vulnerability in trunk wood of conifer trees with and without symptoms of top dieback. J. Plant Hydraulics 3:e001. Available online at: http://scholar.google.fr/citations?view_op=view_citation\&hl=fr\& user=6tDX42gAAAAJ\&citation_for_view=6tDX42gAAAAJ:YsMSGLbcyi4C

Rosner, S., Svitlík, J., Andreassen, K., Børja, I., D alsgaard, L., Evans, R., et al. (2016a). Novel hydraulic vulnerability proxies for a boreal conifer species reveal that opportunists may have lower survival prospects under extreme climatic events. Front. Plant Sci. 7:831. doi: 10.3389/fpls.2016. 00831
Rossi, S., Anfodillo, T., Ėufar, K., Cuny, H., Deslauriers, A., Fonti, P., et al. (2013). A meta-analysis of cambium phenology and growth: linear and nonlinear patterns in confers of the norther hemisphere. Ann. Bot. 112, 1911-1920. doi: $10.1093 / \mathrm{aob} / \mathrm{mct} 288$

Salmon, Y., Torres-Ruiz, J. M., Poyatos, R., Martinez-Vilalta, J., Meir, P., Cochard, H., et al. (2015). Balancing the risks of hydraulic failure and carbon starvation: a twig scale analysis in declining Scots pine. PCE 38, 2575-2588. doi: $10.1111 /$ pce. 12572

Schiestl-Aalto, P., Kulmala, L., Makinen, H., Nikinmaa, E., and Makela, A. (2015). CASSIA - a dynamic model for predicting intra-annual sink demand and interannual growth variation in Scots pine. New Phytol. 206, 647-659. doi: $10.1111 /$ nph.13275

Smith, M. D. (2011). An ecological perspective on extreme climatic events: a synthetic definition and framework to guide future research. J. Ecol. 99, 656-663. doi: 10.1111/j.1365-2745.2011.01798

Steppe, K., De Pauw, D. J. W., Lemeur, R., and Vanrolleghem, P. A. (2006). A mathematical model linking tree sap flow dynamics to daily stem diameter fluctuations and radial stem growth. Tree Physiol. 26, 257-273. doi: 10.1093/treephys/26.3.257

Steppe, K., Sterck, F., and Deslauriers, A. (2015). Diel growth dynamics in tree stems: linking anatomy and ecophysiology. Trends Plant Sci. 20, 335-343. doi: 10.1016/j.tplants.2015.03.015

Steppe, K., von der Crone, J. S., and De Pauw, D. J. W. (2016). TreeWatch.net: a water and carbon monitoring and modeling network to assess instant tree hydraulics and carbon status. Front. Plant Sci. 7:993. doi: 10.3389/fpls.2016.00993

Sterck, F., Zuidema, P., Anten, N. P., and Schieving, F. (2016). Trait acclimation mitigates mortality risks of tropical canopy trees under global warming. Front. Plant Sci. 7:607. doi: 10.3389/fpls.2016.00607

Teskey, R. O., Wertin, T. M., Bauweraerts, I., Ameye, M., McGuire, M. A., and Steppe, K. (2015). Responses of tree species to heat waves and extreme heat events. PCE 38, 1699-1712. doi: 10.1111/pce.12417

von Arx, G., and Carrer, M. (2014). ROXAS-A new tool to build centuries-long tracheid-lumen chronologies in conifers. Dendrochronologia 32, 290-293. doi: 10.1016/j.dendro.2013.12.001

von Arx, G., Crivellaro, A., Prendin, A. L., Cufar, K., and Carrer, M. (2016). Quantitative wood anatomy - practical guidelines. Front. Plant Sci. 7:751. doi: 10.3389/fpls.2016.00751

Wullschleger, S. D., Epstein, H. E., Box, E. O., Euskirchen, E. S., Goswami, S., Iversen, et al. (2014). Plant functional types in Earth system models: past experiences and future directions for application of dynamic vegetation models in high-latitude ecosystems. Ann. Bot. 114, 1-16. doi: 10.1093/aob/mcu077

Zalloni, E., De Luis, M., Campelo, F., Novak, K., De Micco, V., Di Filippo, A., et al. (2016). Climatic signals from intra-annual density fluctuation frequency in mediterranean pines at a regional scale. Front. Plant Sci. 7:579. doi: 10.3389/fpls.2016.00579

Conflict of Interest Statement: The authors declare that the research was conducted in the absence of any commercial or financial relationships that could be construed as a potential conflict of interest.

Copyright (c) 2016 Sass-Klaassen, Fonti, Cherubini, Gričar, Robert, Steppe and Bräuning. This is an open-access article distributed under the terms of the Creative Commons Attribution License (CC BY). The use, distribution or reproduction in other forums is permitted, provided the original author(s) or licensor are credited and that the original publication in this journal is cited, in accordance with accepted academic practice. No use, distribution or reproduction is permitted which does not comply with these terms. 